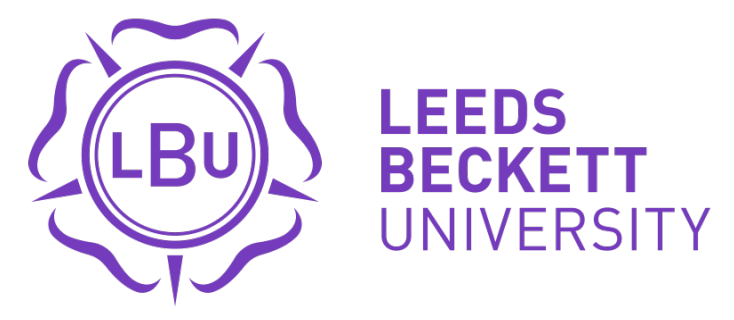

Citation:

Giuntoli, G and Hughes, S and Karban, K and South, J (2015) Towards a middle-range theory of mental health and well-being effects of employment transitions: Findings from a qualitative study on unemployment during the 2009-2010 economic recession. Health (London, England : 1997), 19 (4). 389 - 412. ISSN 1363-4593 DOI: https://doi.org/10.1177/1363459314554314

Link to Leeds Beckett Repository record:

https://eprints.leedsbeckett.ac.uk/id/eprint/1236/

Document Version:

Article (Accepted Version)

The aim of the Leeds Beckett Repository is to provide open access to our research, as required by funder policies and permitted by publishers and copyright law.

The Leeds Beckett repository holds a wide range of publications, each of which has been checked for copyright and the relevant embargo period has been applied by the Research Services team.

We operate on a standard take-down policy. If you are the author or publisher of an output and you would like it removed from the repository, please contact us and we will investigate on a case-by-case basis.

Each thesis in the repository has been cleared where necessary by the author for third party copyright. If you would like a thesis to be removed from the repository or believe there is an issue with copyright, please contact us on openaccess@leedsbeckett.ac.uk and we will investigate on a case-by-case basis. 


\title{
Towards a middle-range theory of mental health and well-being effects of employment transitions: Findings from a qualitative study on unemployment during the 2009-2010 economic recession
}

\begin{abstract}
This paper builds upon previous theoretical work on job loss as a status passage to help explain how people's experiences of involuntary unemployment affected their mental well-being during the 2009-2010 economic recession. It proposes a middle-range theory that interprets employment transitions as status passages and suggests that their health and well-being effects depend on the personal and social meanings that people give to them, which are called properties of the transitions. The analyses, which used a thematic approach, are based on the findings of a qualitative study undertaken in Bradford (North England) consisting of 73 people interviewed in 16 focus groups. The study found that the participants experienced their job losses as divestment passages characterised by three main properties: experiences of reduced agency, disruption of role-based identities, e.g. personal identity crises, and experiences of 'spoiled identities', e.g. experiences of stigma. The proposed middle-range theory allows to federate these findings together in a coherent framework which makes a contribution to illuminating not just the intra-personal consequences of unemployment, i.e. its impact on subjective well-being and common mental health problems, but also its inter-personal consequences, i.e. the hidden and often overlooked social processes that affect unemployed people's social well-being. The paper discusses how the study findings and the proposed middle-range theory can help to address the theoretical weaknesses and often contradictory empirical findings from studies that use alternative frameworks, e.g. deprivation models and 'incentive theory' of unemployment.
\end{abstract}

This is the accepted manuscript version for the article published in Health (London):

Giuntoli, G., Hughes, S., Karban, K., \& South, J. (2014). Towards a middle-range theory of mental health and well-being effects of employment transitions: Findings from a qualitative study on unemployment during the 2009-2010 economic recession. Health (London) Published online before print October 15, 2014, doi: 10.1177/1363459314554314 


\section{Introduction}

A substantial body of literature shows that unemployment is associated with poorer mental health and well-being conceptualised as life satisfaction (Paul and Moser, 2009; Wanberg, 2012; McKee-Ryan et al., 2005). Previous research indicates that prevalence rate of psychological problems is more than double among the unemployed compared to the employed (Paul and Moser, 2009), and that unemployed people are two to three times more at risk of death by suicide compared to fully employed people (Gunnell et al., 2009). Lucas et al. (2004) found that unemployment is one of the few life events (another is bereavement) that can change people's life satisfaction set-point; participants did not return to their original life satisfaction baseline even many years after they regained employment. Overall, several authors agree that, even after accounting for the links between prior illness and unemployment (e.g. health selection or drift hypothesis, and residue hypothesis), a proportion of the association between unemployment and poorer mental health is causal and therefore requires research and policy attention (e.g. Gunnell et al., 2009; Wanberg, 2012).

Despite such a body of evidence on the effects of unemployment on mental health and life satisfaction, there is still a paucity of research on the relationships between unemployment and the broader range of well-being variables. In both the systematic reviews of McKee-Ryan et al. (2005) and Paul and Moser (2009), about three quarters of the correlations analysed concerned mental health, e.g. depression scales, measures of anxiety and measures of current mental health such as the General Health Questionnaire, and only about a quarter included broader measures of well-being ${ }^{1}$. In particular, these latter ones consisted primarily of measures of hedonic well-being, i.e. how good people feel about their lives, which comprised measures of 'subjective well-being' (i.e. positive affect and life satisfaction) in Paul and Moser (2009) and life satisfaction in McKee-Ryan et al. (2005). Measures of eudaimonic well-being, which refer to how

${ }^{1}$ This ratio is mentioned in McKee-Ryan et al. (2005: 66) regarding their own article; for Paul's and Moser's (2009) article, we have calculated it from Table 1 at page 271.

This is the accepted manuscript version for the article published in Health (London):

Giuntoli, G., Hughes, S., Karban, K., \& South, J. (2014). Towards a middle-range theory of mental health and well-being effects of employment transitions: Findings from a qualitative study on unemployment during the 2009-2010 economic recession. Health (London) Published online before print October 15, 2014, doi: 10.1177/1363459314554314 
well unemployed people function in life, both socially, i.e. their 'social well-being' (Keyes and Annas, 2009), and in relation to their existential concerns and evaluations of self-realisation, i.e. their 'psychological well-being' (Keyes and Annas, 2009), were included only by McKee-Ryan et al. (2005), who explored marital and family satisfaction, although only a small number of studies was found. Nevertheless, research shows that the study of both the hedonic and the eudaimonic components of well-being - which, to keep with the current terminology in the UK, is here referred to as mental well-being (Welch et al., 2011) - is more effective to predict mental illness than the mere study of hedonic well-being (Keyes and Annas, 2009) and that low mental wellbeing (defined as 'languishing', i.e. not feeling good about and not functioning well in life) can have an important cost for societies over and beyond that of mental illness (Keyes and Annas, 2009).

Among the frameworks that explicate the relationships between unemployment and mental health and well-being, which are discussed in the following section, only some are complex enough to refer both to hedonic well-being and eudaimonic well-being. Overall, current research results suggest the need to develop models which are both multidisciplinary and multidimensional to explain the links between unemployment and health in more detail (Janlert and Hammarstrom, 2009). However, such models should overcome the limits that have so far characterized even the most complex proposals, such as for example Jahoda's (1982) latent model and Warr's (1987) vitamin model, which have fallen short of providing a framework that fully accounts for unemployed people's own perspectives and helps to understand how their different experiences relate to each other and impact on the main components of their mental well-being (Ezzy, 1993). Dooley and Prause (2004) highlighted the further need to account for the contemporary flexibilisation of the job markets and proposed to conceive employment status as a continuum, i.e. from adequate employment, to inadequate employment, to unemployment, rather than as a dichotomy. Their study has found that the impact of inadequate employment

This is the accepted manuscript version for the article published in Health (London):

Giuntoli, G., Hughes, S., Karban, K., \& South, J. (2014). Towards a middle-range theory of mental health and well-being effects of employment transitions: Findings from a qualitative study on unemployment during the 2009-2010 economic recession. Health (London) Published online before print October 15, 2014, doi: 10.1177/1363459314554314 
(e.g. involuntary part-time or low hours, low wage jobs) on people's mental well-being more resembles unemployment than adequate employment.

We suggest that the development of multidimensional models to explain the links between unemployment, mental health and well-being requires qualitative studies aimed at unravelling these complexities. Existing literature that has investigated wider aspects of unemployed people's well-being, including their eudaimonic component, either has been theoretically driven in the choice of relevant dimensions, or has quantitative research designs (e.g. Welch et al., 2011). Qualitative research on people's experiences of unemployment has either focused on the experiences of job loss or return to work of people with mental health problems (e.g. Boyce et al., 2008), or has explored the 'narrative plots' through which people make sense of job losses in their lives (e.g. Ezzy, 2001; Gabriel et al., 2010). This latter type of study entails a primary focus on the intra-personal effects of unemployment in people's lives and a minimal account of its inter-personal consequences, which are at the basis of important aspects of people's eudaimonic well-being, e.g. their social well-being.

This paper builds upon previous theoretical work on social status and identity to suggest a framework that can advance our understanding of the pathways by which the experiences of unemployed people can affect both main components of their mental well-being, i.e. their hedonic well-being and their eudaimonic well-being. It is based on the findings of a qualitative study that was undertaken in Bradford, a city in northern England, and involved people who were made jobless during the $2009-2010$ recession. The Bradford study objectives were to examine the participants' experiences of unemployment and to explore how these related to their experiences of mental health and well-being.

The paper is divided into four main sections. The first section briefly reviews and critically discusses the main models explaining the health effect of unemployment and proposes a middle-range theory aimed to explicate the relationship between unemployment and mental

This is the accepted manuscript version for the article published in Health (London):

Giuntoli, G., Hughes, S., Karban, K., \& South, J. (2014). Towards a middle-range theory of mental health and well-being effects of employment transitions: Findings from a qualitative study on unemployment during the 2009-2010 economic recession. Health (London) Published online before print October 15, 2014, doi: 10.1177/1363459314554314 
health and well-being (Ezzy, 1993). The second and third sections report respectively on the methods and findings of the Bradford study, and the fourth discusses the study findings in the context of the wider literature and draws the conclusions.

\section{How unemployment affects people's mental health and well-being}

To overcome the theoretical and empirical limits mentioned above (see table 1), Ezzy (1993) proposed a middle-range theory in which job losses are interpreted as a status passage, that is an individual's movement into a different part of the social ladder which can lead to a changed identity, sense of self, and behaviour. Ezzy (1993) conceptualises status passages along a continuum. At one extreme is 'integrative passages', which are usually 'positive achievements' and consist of an "integration into a clearly delineated new status entered through a ceremonially specified process" (pp. 48-49), e.g. marriages, and at the other 'divestment passages', which are usually negatively achieved and entail a "separation from a status and often contain extended transitional phases of uncertain duration", e.g. divorce (p. 49). The conceptualisation of divestment and integrative passages as extremes categories of a continuum is important; it allows the creation of intermediate forms of passage which can account for the tension that often exists between the nature of the passage, whether 'divesting' or integrating, and its direction, whether upward or downward. As Ezzy states, "even integration into deviant statuses such as becoming a criminal, or certified insane involve the acquisition of an identity, rather than simply the loss of publicly acceptable statuses" (p. 49), however, such integrations would not usually be considered as a movement upward on the social ladder. In particular, Ezzy (1993) proposes that job loss leading into unemployment is an example of a divestment passage. This entails considering this form of job loss not as a static experience, but rather as a process which is characterised by three phases: a separation, which is caused by the event that leads to becoming jobless, a transitory phase, which is the phase of unemployment, and possibly an integrative passage into another role/status.

This is the accepted manuscript version for the article published in Health (London):

Giuntoli, G., Hughes, S., Karban, K., \& South, J. (2014). Towards a middle-range theory of mental health and well-being effects of employment transitions: Findings from a qualitative study on unemployment during the 2009-2010 economic recession. Health (London) Published online before print October 15, 2014, doi: 10.1177/1363459314554314 
Table 1. Examples of models that explain the relationships between unemployment and mental health and well-being (MH\&WB)

\begin{tabular}{|c|c|c|c|c|c|c|}
\hline Models \& theories & $\begin{array}{l}\text { Main } \\
\text { reference }\end{array}$ & Theoretical basis & $\begin{array}{l}\text { Mechanism } \\
\text { (Unemployment is } \\
\text { detrimental to people's } \\
\text { MH\&WB because...) }\end{array}$ & Affecting factors & Strengths & Limitations \\
\hline \multicolumn{7}{|l|}{$\begin{array}{l}\text { Multidimensional } \\
\text { models }\end{array}$} \\
\hline Latent functions model & $\begin{array}{l}\text { Jahoda } \\
\text { (1982) }\end{array}$ & Needs-based & $\begin{array}{l}\text {...Jobless people cannot } \\
\text { satisfy their material and } \\
\text { psychological needs. }\end{array}$ & $\begin{array}{l}\text { - Material needs } \\
\text { - Five latent psychological } \\
\text { needs: Having a daily time } \\
\text { structure; Socialising with } \\
\text { others; a sense of purpose; } \\
\text { Knowing one's social status; } \\
\text { Being active. }\end{array}$ & $\begin{array}{l}\text { - Covers both } \\
\text { material and } \\
\text { psychological } \\
\text { needs }\end{array}$ & $\begin{array}{l}\text { - Passive view: People } \\
\text { depend on employment } \\
\text { to satisfy their } \\
\text { psychological needs. } \\
\text { - Situation-centred: Ignores } \\
\text { people's own } \\
\text { interpretations of their } \\
\text { circumstances. } \\
\text { - Focus on lack of work per } \\
\text { se, however, low paid or } \\
\text { insecure employment } \\
\text { may also fail to meet } \\
\text { people's material and } \\
\text { psychological needs. }\end{array}$ \\
\hline Vitamin model & Warr (1987) & Needs-based & $\begin{array}{l}\text {... It is a social condition } \\
\text { which consist of nine key } \\
\text { factors that are to MH\&WB } \\
\text { as vitamins are to physical } \\
\text { health. }\end{array}$ & $\begin{array}{l}\text { - Nine 'vitamins': } \\
\text { Opportunity for control; } \\
\text { opportunity for skill use; } \\
\text { externally generated goals; } \\
\text { variety; environmental } \\
\text { clarity; availability of } \\
\text { money; physical security; } \\
\text { interpersonal contact; } \\
\text { valued social position. }\end{array}$ & $\begin{array}{l}\text { - Accounts for } \\
\text { forms of } \\
\text { employment that } \\
\text { can have } \\
\text { negative effects } \\
\text { on MH\&WB. }\end{array}$ & $\begin{array}{l}\text { - Situation-centred (see } \\
\text { above) }\end{array}$ \\
\hline $\begin{array}{l}\text { Middle-range theory of } \\
\text { job loss as a status }\end{array}$ & Ezzy (1993) & $\begin{array}{l}\text { Interpretation- } \\
\text { based }\end{array}$ & $\begin{array}{l}\text {...It is a divestment } \\
\text { (downward) status passage }\end{array}$ & $\begin{array}{l}\text { - The 'properties' of the } \\
\text { status passage, in particular }\end{array}$ & $\begin{array}{l}\text { - Accounts for } \\
\text { individual }\end{array}$ & $\begin{array}{l}\text { - Requires reach data and } \\
\text { analyses. }\end{array}$ \\
\hline
\end{tabular}

Giuntoli, G., Hughes, S., Karban, K., \& South, J. (2014). Towards a middle-range theory of mental health and well-being effects of employment transitions: Findings from a qualitative study on unemployment during the 2009-2010 economic recession. Health (London) Published online before print October 15, 2014, doi: 10.1177/1363459314554314 


\begin{tabular}{|c|c|c|c|c|c|c|}
\hline Models \& theories & $\begin{array}{c}\text { Main } \\
\text { reference }\end{array}$ & Theoretical basis & $\begin{array}{c}\text { Mechanism } \\
\text { (Unemployment is } \\
\text { detrimental to people's } \\
\text { MH\&WB because...) }\end{array}$ & Affecting factors & Strengths & Limitations \\
\hline passage & & & $\begin{array}{l}\text { that can involve central } \\
\text { identities, e.g. professional } \\
\text { identities, and disrupt } \\
\text { people's strategies to } \\
\text { sustain consistent and } \\
\text { positive self-images. }\end{array}$ & central identities. & $\begin{array}{l}\text { interpretations of } \\
\text { job loss } \\
\text { experiences. } \\
\text { - Offers novel } \\
\text { explanation } \\
\text { based on identity } \\
\text { theory. }\end{array}$ & $\begin{array}{l}\text { - Not been empirically } \\
\text { tested. } \\
\text { - Disregards insights from } \\
\text { 'social identity theory'. }\end{array}$ \\
\hline Set-point theory & $\begin{array}{l}\text { Lucas et al. } \\
(2004)\end{array}$ & $\begin{array}{l}\text { Homeostatic- } \\
\text { based }\end{array}$ & $\begin{array}{l}\text {...people experience stress } \\
\text { and negative emotions } \\
\text { which reduce their well- } \\
\text { being, although this } \\
\text { eventually will return to its } \\
\text { original set-point. }\end{array}$ & $\begin{array}{l}\text { - People's well-being set- } \\
\text { point is established by } \\
\text { personality and genetic } \\
\text { traits, not by external } \\
\text { factors. Nevertheless, it is } \\
\text { acknowledged that } \\
\text { different external factors } \\
\text { can disrupt people's } \\
\text { homeostatic equilibrium } \\
\text { and reduce their well-being. }\end{array}$ & $\begin{array}{l}\text { - Focuses on } \\
\text { people's } \\
\text { emotions and life } \\
\text { satisfaction. }\end{array}$ & $\begin{array}{l}\text { - 'Top-down' approach: it is } \\
\text { based on the assumption } \\
\text { that well-being tends to a } \\
\text { set-point level which is } \\
\text { established by personality } \\
\text { and genetic heritage, not } \\
\text { by people's experiences } \\
\text { (bottom up approach). } \\
\text { So, people's life } \\
\text { circumstances have little } \\
\text { role in explaining their } \\
\text { well-being. They can } \\
\text { deflect people's well- } \\
\text { being below their set- } \\
\text { point, but eventually this } \\
\text { will return to its original } \\
\text { level because it is } \\
\text { regulated by homeostatic } \\
\text { mechanisms. }\end{array}$ \\
\hline Incentive theory & $\begin{array}{l}\text { Ervasti and } \\
\text { Venetoklis } \\
(2010)\end{array}$ & $\begin{array}{l}\text { Structural } \\
\text { interpretation / } \\
\text { supply-side based }\end{array}$ & $\begin{array}{l}\text {...People experience } \\
\text { economic and psychological } \\
\text { disincentives to re-join the } \\
\text { labour market due to over- } \\
\text { generous welfare systems. }\end{array}$ & $\begin{array}{l}\text { - Availability of leisure time } \\
\text { and welfare benefits. }\end{array}$ & $\begin{array}{l}\text { - Focuses on } \\
\text { people's agency. }\end{array}$ & $\begin{array}{l}\text { - Disregards people's } \\
\text { structural opportunities } \\
\text { and the material and } \\
\text { psychological impact that } \\
\text { unemployment can have. } \\
\text { - No empirical support } \\
\text { found for the }\end{array}$ \\
\hline
\end{tabular}

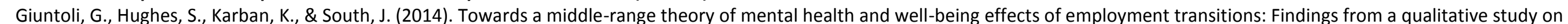
unemployment during the 2009-2010 economic recession. Health (London) Published online before print October 15, 2014, doi: 10.1177/1363459314554314 


\begin{tabular}{|c|c|c|c|c|c|c|}
\hline Models \& theories & $\begin{array}{c}\text { Main } \\
\text { reference }\end{array}$ & Theoretical basis & $\begin{array}{c}\text { Mechanism } \\
\text { (Unemployment is } \\
\text { detrimental to people's } \\
\text { MH\&WB because...) }\end{array}$ & Affecting factors & Strengths & Limitations \\
\hline & & & & & & $\begin{array}{l}\text { assumptions of the } \\
\text { incentive model regarding } \\
\text { the levels of financial and } \\
\text { well-being satisfaction } \\
\text { among unemployed } \\
\text { people. }\end{array}$ \\
\hline \multicolumn{7}{|l|}{ Single-cause models } \\
\hline Time or stage models & $\begin{array}{l}\text { Eisenberg } \\
\text { and } \\
\text { Lazarsfeld } \\
(1938)\end{array}$ & Time-based & $\begin{array}{l}\text {...People experience a range } \\
\text { of consistent and time } \\
\text { based responses from initial } \\
\text { optimism, to stress and } \\
\text { anxiety, to final stage of } \\
\text { depression and resignation. }\end{array}$ & • Unemployment length. & $\begin{array}{l}\text { - Refers to } \\
\text { people's } \\
\text { experience of } \\
\text { time. }\end{array}$ & $\begin{array}{l}\text { Disregards the complex } \\
\text { processes that } \\
\text { characterise experiences } \\
\text { of unemployment. }\end{array}$ \\
\hline Agency theory & Fryer (1986) & Agency-based & $\begin{array}{l}\text {...Financial strain deprives } \\
\text { people of capacity of pursue } \\
\text { their goals. }\end{array}$ & $\begin{array}{l}\text { - Accounts for financial } \\
\text { impact of unemployment. } \\
\text { - Unemployed people seen as } \\
\text { active agents with goals } \\
\text { who strive to make sense of } \\
\text { their reality. }\end{array}$ & $\begin{array}{l}\text { - Focuses on } \\
\text { people's agency. }\end{array}$ & $\begin{array}{l}\text { - Does not account for the } \\
\text { non-material effects of } \\
\text { unemployment on } \\
\text { people's MH\&WB. }\end{array}$ \\
\hline $\begin{array}{l}\text { Incongruence } \\
\text { hypothesis }\end{array}$ & $\begin{array}{l}\text { Paul and } \\
\text { Moser (2006) }\end{array}$ & Psychology-based & $\begin{array}{l}\text {...People experience } \\
\text { incongruence between their } \\
\text { values (high commitment to } \\
\text { work) and their reality (no } \\
\text { work). }\end{array}$ & - People's expectations. & $\begin{array}{l}\text { Focuses on } \\
\text { people's beliefs. }\end{array}$ & $\begin{array}{l}\text { Does not account for } \\
\text { material and wider non- } \\
\text { material effects of } \\
\text { unemployment on } \\
\text { MH\&WB. }\end{array}$ \\
\hline
\end{tabular}


Status passages present several properties, which are the characteristics of the status passage as experienced by people. Such properties are key to understand whether people's status passages are going to have positive or negative consequences on their mental health and well-being. In this respect, Ezzy's framework is similar to the 'employment continuum' approach in that it acknowledges that different forms of job loss and pathways into unemployment (e.g. unemployment because of ill-health, because of redundancy, retirement, leaving school, etc.) and out of unemployment (e.g. satisfactory employment as opposed to various forms of underemployment, or substitutes of employment) may lead to different forms of status passage, present different properties and therefore affect people's mental well-being differently. This latter assumption is consistent with recent research that shows significant variations in the hedonic and eudaimonic well-being of unemployed people (i.e. jobless but available and looking for a job), people economically inactive but not retired, and retired people (Welch et al., 2011).

In particular, Ezzy (1993) draws on identity theory (Strycker, 1980) and suggests that an important property of status passages is whether they involve social roles that are central in defining people's identities. From this point of view and consistently with other proposals, unemployment is likely to have a negative impact on the mental health and well-being of all those people for whom their work-roles are central in defining their personal identities and who cannot find satisfying alternative identities after becoming unemployed. However, in sociology and social psychology the phenomenon of people's identities is also investigated by 'social identity theory' (Stets and Burke, 2000), which focuses on groups as bases for identity formation (not social roles, as in identity theory) and conceptualises identities as people's awareness of belonging to a group or social category, for example 'employed' as opposed to 'unemployed' (whereas in identity theory identities are conceptualised as 'internalised role expectations'). Social identity theory helps to identify and explain the relationships between the experience of unemployment, the meanings and interpretations

This is the accepted manuscript version for the article published in Health (London): 
that people give to it and various psychological outcomes. For example, self-esteem or lack of it can depend on whether people value positively or negatively the social categories with which they identify. Also, social identities can enhance people's well-being by providing the basis for individuals to receive and benefit from social support (Haslam et al., 2009).

Referring to both identity and social identity theory can help to better understand the ways in which people experience the status passages and identity changes brought about by unemployment and, therefore, how such passages and changes can affect both the hedonic and the eudaimonic components of unemployed people's mental well-being. The following sections of this paper draw on the theoretical insights underpinning the proposed elaborated version of Ezzy's (1993) middle-range theory to interpret the findings of the Bradford study and to help understand the relationships between mental well-being and the experience of involuntary unemployment at times of economic recession.

\section{Methods}

The study presented in this paper consisted of 16 focus groups with a total of 73 people, 33 men and 40 women who lost their jobs at any point from July 2008 to October 2010; people who left their jobs out of choice were not eligible for this study. July 2008 represents the start of the two quarters of negative economic growth that led Britain to officially enter recession in January 2009, the assumption being that participants were made jobless as a consequence of the economic downturn.

The Bradford study (see above) had a particular focus on possible age and gender related differences in relation to the participants' experiences of service use, so the focus groups were divided in separate gender and age groups: 7 were with participants aged 17-25 (4 with women and 3 with men), 5 with participants aged 26-49 (3 with women and 2 with men), and 4 with participants aged 50-65 (1 with women and 3 with men). Some socio-demographic

This is the accepted manuscript version for the article published in Health (London): 
information regarding the participants can be found in Table 2, which shows that the sample consisted primarily of people who were previously employed in routine, semi-routine and technical jobs. A short self-administered questionnaire was used to collect some basic health information from the participants. This showed that the prevalence rate of common mental health problems among the study participants (23\%) was in line with the national norm of about 25\% (Mind, 2013).

Table 2. Number of study participants by age groups, ethnicity, lenght of unemployment, and employment backgrounds.

\begin{tabular}{|c|c|c|c|}
\hline \multirow[t]{2}{*}{ Demographic characteristics } & \multicolumn{2}{|c|}{ Gender* } & \multirow[b]{2}{*}{ Total $^{\dagger}$} \\
\hline & Female & Male & \\
\hline \multicolumn{4}{|l|}{ Age groups $(n=69)$} \\
\hline $17-25$ & $\begin{array}{c}21 \\
(57)\end{array}$ & $\begin{array}{c}16 \\
(43)\end{array}$ & $\begin{array}{l}37 \\
(54)\end{array}$ \\
\hline $26-49$ & $\begin{array}{c}14 \\
(78)\end{array}$ & $\begin{array}{c}4 \\
(22)\end{array}$ & $\begin{array}{c}18 \\
(26)\end{array}$ \\
\hline $50-65$ & $\begin{array}{c}5 \\
(36)\end{array}$ & $\begin{array}{c}9 \\
(64)\end{array}$ & $\begin{array}{c}14 \\
(20)\end{array}$ \\
\hline \multicolumn{4}{|l|}{ Ethnic background $(\mathrm{n}=69)$} \\
\hline White British & $\begin{array}{l}38 \\
(61)\end{array}$ & $\begin{array}{c}24 \\
(39)\end{array}$ & $\begin{array}{c}62 \\
(85)\end{array}$ \\
\hline Others (White Other, Black and Asian) & $\begin{array}{c}2 \\
(29)\end{array}$ & $\begin{array}{c}5 \\
(71)\end{array}$ & $\begin{array}{c}7 \\
(15)\end{array}$ \\
\hline \multicolumn{4}{|l|}{ Length of unemployment $(n=63)$} \\
\hline$<6$ months & $\begin{array}{c}5 \\
(71)\end{array}$ & $\begin{array}{c}2 \\
(29)\end{array}$ & $\begin{array}{c}7 \\
(11)\end{array}$ \\
\hline$>6$ months & $\begin{array}{c}32 \\
(57)\end{array}$ & $\begin{array}{c}24 \\
(43)\end{array}$ & $\begin{array}{l}56 \\
(89)\end{array}$ \\
\hline \multicolumn{4}{|l|}{$\begin{array}{l}\text { Had previous experience of unemployment } \\
(n=69)\end{array}$} \\
\hline Yes & $\begin{array}{c}32 \\
(56)\end{array}$ & $\begin{array}{l}25 \\
(44)\end{array}$ & $\begin{array}{c}57 \\
(82)\end{array}$ \\
\hline No & $\begin{array}{c}8 \\
(67)\end{array}$ & $\begin{array}{c}4 \\
(33)\end{array}$ & $\begin{array}{c}12 \\
(18)\end{array}$ \\
\hline \multicolumn{4}{|l|}{ Previous occupation $(n=53)$} \\
\hline $\begin{array}{l}\text { Modern professional occupations: } \\
\text { teacher, nurse, social worker }\end{array}$ & $\begin{array}{c}6 \\
(86)\end{array}$ & $\begin{array}{c}1 \\
(14)\end{array}$ & $\begin{array}{c}7 \\
(13)\end{array}$ \\
\hline
\end{tabular}

This is the accepted manuscript version for the article published in Health (London): 


\begin{tabular}{|c|c|c|c|}
\hline \multirow[t]{2}{*}{ Demographic characteristics } & \multicolumn{2}{|c|}{ Gender* } & \multirow[b]{2}{*}{ Total $^{\dagger}$} \\
\hline & Female & Male & \\
\hline $\begin{array}{l}\text { Clerical and intermediate occupations: } \\
\text { secretary, call centre agent }\end{array}$ & $\begin{array}{c}4 \\
(100)\end{array}$ & 0 & $\begin{array}{c}4 \\
(7)\end{array}$ \\
\hline $\begin{array}{l}\text { Senior managers or administrators: } \\
\text { finance manager, chief executive }\end{array}$ & $\begin{array}{c}1 \\
(50)\end{array}$ & $\begin{array}{c}1 \\
(50)\end{array}$ & $\begin{array}{c}2 \\
(4)\end{array}$ \\
\hline $\begin{array}{l}\text { Technical and craft occupations: motor } \\
\text { mechanic, electrician }\end{array}$ & $\begin{array}{c}7 \\
(87)\end{array}$ & $\begin{array}{c}1 \\
(13)\end{array}$ & $\begin{array}{c}8 \\
(15)\end{array}$ \\
\hline $\begin{array}{l}\text { Semi-routine manual and service } \\
\text { occupations: postal worker, machine } \\
\text { operative, sales assistant }\end{array}$ & $\begin{array}{c}7 \\
(64)\end{array}$ & $\begin{array}{c}4 \\
(36)\end{array}$ & $\begin{array}{c}11 \\
(21)\end{array}$ \\
\hline $\begin{array}{l}\text { Routine manual and service occupations: } \\
\text { Van driver, cleaner, labourer, } \\
\text { waiter/waitress }\end{array}$ & $\begin{array}{c}6 \\
(33)\end{array}$ & $\begin{array}{c}12 \\
(67)\end{array}$ & $\begin{array}{c}18 \\
(34)\end{array}$ \\
\hline $\begin{array}{l}\text { Middle or junior managers: } \\
\text { office manager }\end{array}$ & 0 & $\begin{array}{c}1 \\
(100)\end{array}$ & $\begin{array}{c}1 \\
(2)\end{array}$ \\
\hline $\begin{array}{l}\text { Traditional professional occupations: } \\
\text { accountant, solicitor, scientist }\end{array}$ & $\begin{array}{c}1 \\
(50)\end{array}$ & $\begin{array}{c}1 \\
(50)\end{array}$ & $\begin{array}{c}2 \\
(4)\end{array}$ \\
\hline
\end{tabular}

Notes. * Row percentages in parenthesis.

${ }^{\dagger}$ Column percentages in parenthesis calculated excluding missing cases.

The study adopted a purposive, heterogeneous sampling strategy in order to obtain the broadest range of information and perspectives on the experiences of unemployment. The study participants were recruited from July 2010 to October 2010 following three main routes: 'opportunistic' recruitment outside the main Jobcentre Plus in Bradford, through managers of local community centres that run employment programmes, and through two announcements on a local radio station. This strategy aimed at recruiting unemployed people from a variety of work experiences. Some of the focus groups were facilitated by the first author, others by a research assistant.

The focus group schedule started with asking the study participants about their everyday life

This is the accepted manuscript version for the article published in Health (London):

Giuntoli, G., Hughes, S., Karban, K., \& South, J. (2014). Towards a middle-range theory of mental health and well-being effects of employment transitions: Findings from a qualitative study on unemployment during the 2009-2010 economic recession. Health (London) Published online before print October 15, 2014, doi: 10.1177/1363459314554314 
before they lost their job and then moved on to ask about their experiences of job loss, both emotionally and in relation to their social and everyday life, with a particular focus on which sources of help and/or services, if any, they accessed during their unemployment.

Considering the personal and private nature of some of the questions (e.g. the consequences of becoming unemployed), the study participants were asked to comment on short stories, called 'vignettes', which were based on fictitious characters who lost their jobs as a consequence of the economic recession. The aim was to help them to contribute to the discussion without feeling pressured to disclose personal experiences regarding the emotional and everyday life impact of their job loss unless they chose to do so. Although this is a useful technique that can also help to contextualise the questions and obtain more specific answers, it presents its own challenges, both in the phase of data collection, e.g. the clarity of the stories and how believable they are, and in the phase of data analysis, e.g. which elements of the story triggered the participants' answers and what details they tacitly filled in (Finch, 1987). In order to address these issues, we created four sets of vignettes, which differed for the main character's gender and age (young, middle age, and close to retirement), and conducted a small pilot with four participants before starting to use them in each of the gender and age specific focus groups. Each vignette presented two main scenarios, one in which the main character did not have a family and a working partner and one in which they did.

The focus group were transcribed in full and the transcripts analysed using a thematic approach (Braun and Clarke, 2006). This entailed 3 phases: 'coding' of the transcripts; inductive identification of recurring themes; generation of connections between themes and their grouping under more abstract, descriptive concepts, which we interpreted as properties of the participants' status passages (see below). The Computer Assisted Qualitative Data Analysis Software Nvivo 8.0 was used to organise and help with the systematic exploration

This is the accepted manuscript version for the article published in Health (London): 
of the focus groups' transcripts in the coding phase. Statements and discussions that expressed ideas related to people's experiences of unemployment were 'coded', namely highlighted and stored as retrievable text in a 'node' (that is a category) created in NVIVO. Following Miles' and Huberman's (1994) suggestion, a preliminary list of relevant categories (i.e. nodes) was devised before the start of the analysis; this was then enriched during the coding phase. Relevant nodes consisted of the personal, emotional and social experiences, events and episodes that the participants associated with their job loss. For example, the code 'impact on everyday life' was part of the preliminary coding list. This was then expanded by adding a number of 'sub nodes' during the analysis, such as 'emotional impact', 'feeling judged by society', 'financial issues', etc.

The transcript extracts contained in each 'node' in NVIVO were then retrieved and analysed to refine the list of nodes by merging redundant ones and pull them together under common 'themes'. Themes represented overarching personal, emotional and social experiences that cut through several nodes. Only in one instance a theme was the outcome of the information contained in one single node; the theme 'Financial strain' was created drawing primarily on the information contained in the node 'Financial issues'. Six main themes were generated following this methodology. Finally, these were re-analysed by the authors to generate possible connections among them. These analyses and discussions were led by questions aimed to identify the type of status passages that the participants experienced as a result of their job loss and their main properties. These analyses led to the grouping of the six themes under three more abstract concepts that expressed synthetically their relationships and which represent the properties of the status passages that the participants experienced as a result of their job loss.

This is the accepted manuscript version for the article published in Health (London): 
Ethical approval for the study was obtained by the Faculty Ethics Committee. All participants were given an information sheet detailing the project and their rights to withdraw from it within the duration of the study and signed a consent form to participate.

\section{Study findings}

The experience of involuntary unemployment was indeed a divestment passage for all of the study participants. However, involuntary unemployment also led the participants who claimed unemployment benefits to experience an important form of 'integrative passage' in becoming a 'jobseeker', which entailed taking up a new social status and role.

Overall, six themes were generated through the analyses. These affected the study participants' mental well-being through three main pathways, which are here interpreted as properties of the status passages that were brought about by recession-led unemployment:

- reduced agency, which was related to (the themes) experiences of financial strain and difficulties in finding a new job;

- disruption of role-based identities, which was related to (the themes) personal identity crises and loss of time structure and motivation;

- experiences of 'spoiled identities' (Goffman, 1963/1990), which were related to (the themes) 'unemployment stigma' and 'welfare stigma'.

Of the six themes, five were associated with the divestment passage (financial strain, difficulties in finding a new job, personal identity crises, loss of time structure and motivation, and 'unemployment stigma') and one, 'welfare stigma', with the form of integrative passage brought about by involuntary unemployment.

Consistent with previous research, each of the three generated properties was associated with stress and negative emotions, such as anger and frustration, which negatively affected

This is the accepted manuscript version for the article published in Health (London): 
the participants' hedonic well-being. However, the participants' discussions also showed the important effects of these three properties on the two main components of their eudaimonic well-being introduced above: psychological well-being and social-well-being (see Figure 1). These three properties are now introduced more in depth and their implications are then discussed in the final section.

\section{Reduced agency}

Reduced agency was a widely experienced property of the divestment passage brought about by involuntary unemployment; it consisted of a diminished capacity to pursue one's goals and plans, whether short, medium, or long term. Such a diminished capacity to pursue one's goals and plans was directly related to the situation of financial strain that the participants experienced as a result of their job loss, which was prolonged by the difficulties in finding a new job at a time of economic recession.

Financial strain. This consisted of a substantial, often sudden loss of income, as exemplified in the following passage.

l've been unemployed since March, my biggest concern is financially and living 'cos Jobseekers Allowance is only £64 a week and my direct debits a month just for gas, electric all the rest of it is $£ 104$, right? And I get $£ 130$ a fortnight. So one fortnight $£ 104$ is put aside straight away and then l've got $£ 26 / £ 28$ to feed myself... (Women, 26-49).

Financial strain often led to significant, unpredicted and unplanned changes to the participants' lifestyles, such as the inability to afford running a car, paying the rent, paying 
bills, and, in some cases, buying fresh food, which were a source of major stress and negative emotions and so had a negative impact on the participants' hedonic well-being.

This is the accepted manuscript version for the article published in Health (London):

Giuntoli, G., Hughes, S., Karban, K., \& South, J. (2014). Towards a middle-range theory of mental health and well-being effects of employment transitions: Findings from a qualitative study on unemployment during the 2009-2010 economic recession. Health (London) Published online before print October 15, 2014, doi: 10.1177/1363459314554314 
Figure 1. Diagram of the relationships between the job loss status passages and the mental well-being components: hedonic well-being and eudaimonic well-being.
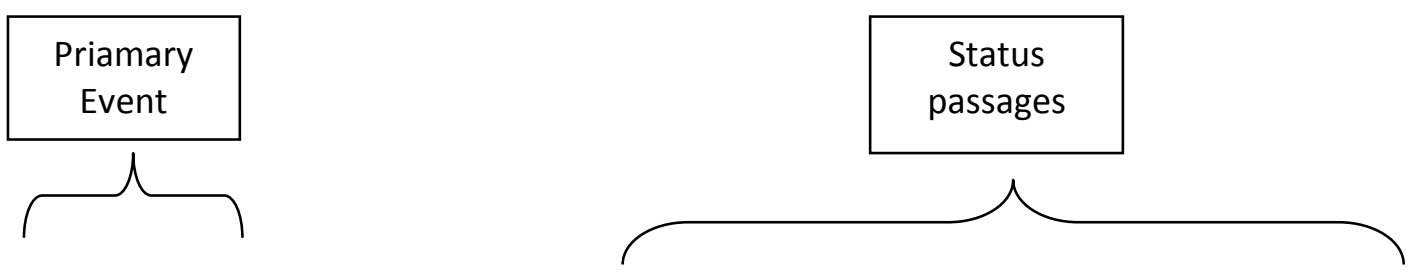

Time

Job loss led to:

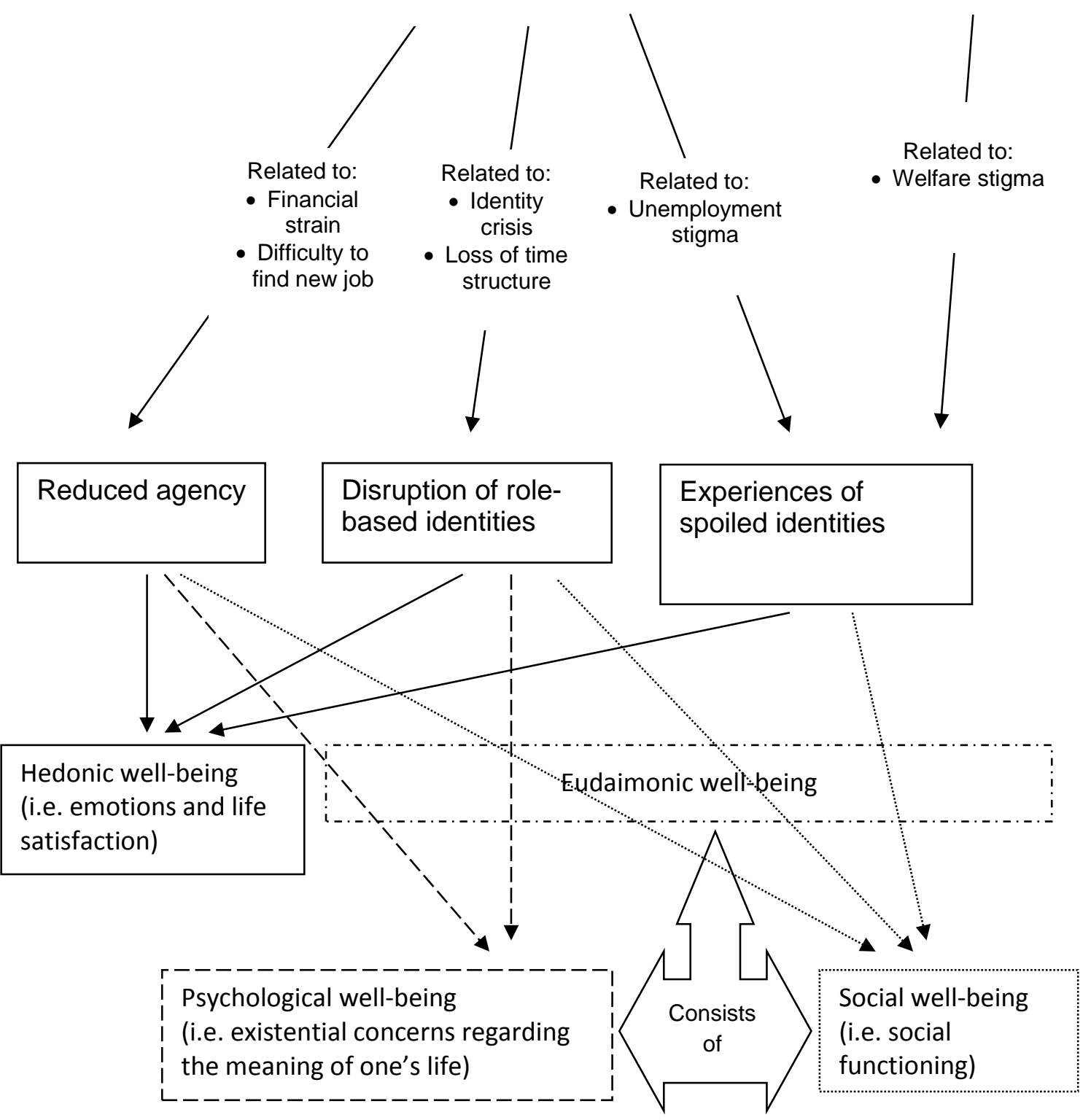

An integrative passage:

(becoming a 'job seeker')

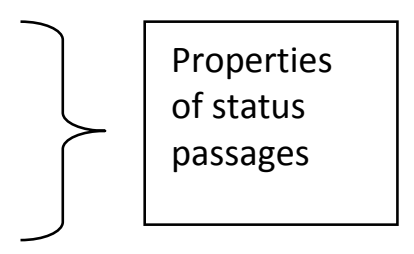

Relationships between properties of the status passages and mental wellbeing components: hedonic wellbeing and eudaimonic

This is the accepted manuscript version for the article published in Health (London):

Giuntoli, G., Hughes, S., Karban, K., \& South, J. (2014). Towards a middle-range theory of mental health and well-being effects of employment transitions: Findings from a qualitative study on unemployment during the 2009-2010 economic recession. Health (London) Published online before print October 15, 2014, doi: 10.1177/1363459314554314 
Difficulties in finding a new job. The effects of financial strain were substantially prolonged and therefore intensified by the participants' difficulties in finding new jobs, which were often associated to the high number of competitors for each single job advertised. The frustration, sense of impotence, and lack of control regarding this issue was also associated to negative emotions such as a sense of despair.

R1: You going down [to the Jobcentre Plus] week in, week out and there might be two or three jobs. By the time you've rung them, forty people's rung them.

R2: Yeah.

R1: And it gets to the point where you think, suck it man. What is the point? Because there's no work out there... (Males, 18-25).

Overall, such a prolonged situation of financial strain led the participants to the experience of reduced agency, that is to an often sudden series of limitations on their freedom of action or choice. In particular, the participants talked of material restrictions, but also and above all of other types of limitations and constraints, which were related to the material ones that were mentioned above, but had a wider nature and implications. The wider types of limitation consisted primarily of the participants' diminished capacity to maintain contacts with their social networks - which affected their social well-being - and fulfil their own expectations, or those of relevant others (e.g. loved ones), in relation to some of the social roles they valued (e.g. parenting), which affected their psychological well-being.

I: What's been the hardest thing from having a job to not having a job?

R1: Money. Not having any money and structure to your day. Not having anything to sort of like get up for to motivate yourself and particularly not being able to live like 
you were able to live when you were working. You know you had good money coming in and all of a sudden it's gone and you're down to $£ 65$ per week.

R2: I agree with that but my most one as well is not being able to do for my little boy what I could do for him and seeing him depressed because he can't have what his friends have got and that is my biggest thing you know.

R3: My biggest thing is kind of social I think because I'm on my own at home. When I were working I could go out and meet up with friends and things and I can't afford to do that now... (Women, 26-49).

R1: Some days you do [feel down] and it gets on top of you. When you've got no money...

R2: Yeah.

R1: ... and your mates are saying, "Let's go somewhere," and all your mates are going somewhere and you've got no money.

R2: Yeah, and, like, l've got mates who are seventeen and they're driving cars and stuff like that.

R1: Yeah.

R2: You take a look at them and...

R1: And you think, what the fuck am I doing?

R2: Yeah, you know what I mean, don't you? 
R1: When all your mates say, "Come on, let's go swimming or let's go to

Flamingoland"...

R2: Yeah.

R1: ....and you can't go 'cause you've got no money and them lot are setting off... (Men, 18-25)

In some cases, the stress and negative emotions generated by the experience of reduced agency led to further strain and stress in family relations, suggesting a further effect on the participants' social well-being.

R1: Me and my missus nearly split up and everything over it 'cause she....just a lack of money, bills to pay.

R2: You're existing, you're not living.

R1: That's it, basically, yeah. [...] It were very hard. We come very close to splitting up, like. It puts a big strain on your family... (Males, 18-25)

Although experiences of reduced agency were widely shared across the study participants, the extent of their effects was related to the amount and nature of support received; for example, whether they received help from their families, redundancy pay, or had substantial savings. With regard to this, and consistently with the framework here proposed, one participant reported that, thanks to his partner's financial support, his experience of job loss led him to start his own business. This event was described as entailing an important expansion of his agency, 'it was the beginning of me taking control of my own life', which can be linked to higher hedonic and eudaimonic well-being and interpreted as implying the 
transformation of his experience of job loss from a divestment passage into a form of upward integrative passage.

R: My experience when we got told that, basically my job was at risk, it just made you feel like a commodity not a human being [...] But luckily enough in my circumstance, I've got a partner who has an income so financially it wasn't that much of a worry, it's just the shock that you've been told that your services are no longer required which seems like an end, but really when I put a positive thought to it, it was the beginning, it was the beginning of me taking control of my own life rather than working for an employer... (Males 26-49).

\section{Disruption of role-based identities}

Disruption of role-based identities was another widely experienced property of the divestment passage prompted by involuntary unemployment; it was related to personal identity crises, which were primarily a consequence of the loss of work-related social roles, and could lead, in a spiral of negative events, to loss of routine and time structure to the day. Such experiences had an immediate negative effect on both the participants' hedonic and psychological well-being, in particular in the form of negative evaluations of self-realisation.

Personal identity crises. For many study participants work had a central role in building their sense of self. The loss of their work-related social roles yielded lower self-esteem and depressive symptoms in many of them. In some cases, as for example in the second quotation below, participants referred to both their social identity, e.g. "As a professional...", and their personal identity, e.g. "as somebody who has been doing...", as crucial factors to explain the effect of their experiences on their mental well-being.

R1:You feel like you're achieving something, don't you, going out and grafting?

This is the accepted manuscript version for the article published in Health (London): 
R2: Yeah. You get the end of the week and you feel a lot better about yourself $[\ldots]$

R1: [When you lose all that] you just feel worthless, you know.

R2: Yeah, it's an horrible feeling, it is... (Men, 18-25)

R1: As a professional, [...] somebody who has been earning good money and just suddenly you are unemployed, you've lost your dignity ...

R2: You're lucky you get through the two weeks (sic).

R1: You've lost your morale, sometimes you recline (sic) to depression... (Men, 5065)

Having a valued 'fall back' social role, such as parenthood and volunteering, was often helpful to compensate the identity disruption related to the loss of one's work-related identity, as it provided the participants with valued work and tasks that motivated them in their everyday life.

R1: My little boy, man. Keeping him happy [...] He's kept me going. [...] otherwise I would have been a tear away. I would have been off....

R2: My gardening project kept me going [...] something to work on every day, you know what I mean, [...] And then after three month, you've got something to show for that, haven't you [All laugh] (Men, 18-25)

R1: The best thing I did was start doing voluntary work. Because you get so down, and feel so useless $[\ldots]$ 
R2: Well, I've got a little dog [...] I've got to take it for a walk otherwise l'd probably get up, I might go on a bus ride out, you know, and then go back to bed, because you feel that low.

R1: Yeah. I think when you're doing volunteer work, it boosts your confidence, you feel you're doing something useful... (Women, 50-65)

Although these were common experiences, in two focus groups the participants discussed how such alternative roles were not full substitutes for their work roles. One woman mentioned her dissatisfaction with being 'just a mum', evidently referring to the loss of social status that she associated with being a working mum. In another focus group, a man said that volunteering did not give him the same 'buzz', that is satisfaction and drive, which he would get from his own profession. The lack of satisfaction of these two participants for the mentioned roles highlights the importance of the eudaimonic components of their mental well-being, such as for example 'purpose in life' and 'personal growth', which refer to the wider goals and plans through which people interpret and ultimately evaluate their experiences.

R1: ...And your confidence disappears.

I: Was that initially, or was that like over a period of time?

R1: Straight away for me.

R2: For me, straight away.

R3: As soon as I lost my job, I felt like I have nothing [...]

R2: You're just a mum [...] You're not yourself.

R3: No... 
R2: [...] I were just a mum. [...] Just someone that does your cooking, your cleaning... (Women, 26-49)

$\mathrm{R} 1:[\ldots]$ the thing is somebody's garden [referring to doing generic volunteering] is not going to give you the same kind of buzz ... it'll give you ... you know, the outlet that you'll be talking to other people and you wouldn't be looking at four walls, but it wouldn't give you the same kind of feelings... (Men, 50-65)

Loss of time structure and motivation. Loss of one's work-role and lack of a 'fall back' role were often conducive to losing time structure and routine to the day. Frequently the study participants discussed this as a frustrating experience that eventually affected their motivation to get out of their home and to engage in social or other activities. Some study participants reported how such a feeling of lack of motivation and boredom degenerated into a depressed mood.

R1: ...When you're working, you have a routine.

R2: Yeah.

R3: And you look at the whole day, don't you, sometimes when you wake up and you think, oh I've got a whole day to fill. You know, and that's depressing, isn't it, if you're on your own... (Women, 50-65)

R1: I get up some days and [...] you're so bored and you know, not knowing what to do or, lack of motivation to do anything after you've had a routine and you try to think, oh, what can I do today... 
R2: I do, I've been so fed up sometimes that l've stayed in bed till like five o'clock. I just can't, l've got up and l've made myself a cuppa and l've just gone back to bed.

R1: It's really hard to motivate yourself isn't it?

R2: Yeah... (Women, 26-49)

\section{Experiences of spoiled identities}

Experiences of 'spoiled identities' (Goffman, 1963/1990) were both a consequence of the divestment passage prompted by involuntary unemployment, which led to experiences of 'unemployed stigma', and a consequence of the important form of 'integrative passage' that the participants experienced during their unemployment: receiving financial help through the welfare system, which led to experiences of 'welfare stigma'. These passages led the participants to become members of social groups with which they did not identify and, in fact, rejected, and therefore had a negative effect on their social well-being, i.e. their evaluations of their public and social lives in relation to their social integration and social acceptance. The experiences of unemployed stigma and welfare stigma differed in relation to their sources and the role that place and social relationships had in characterising them. In particular, unemployed stigma was related to being jobless and the participants talked about it primarily in the context of family relationships. Family members were more likely to know their employment condition and circumstances and so their social identity was more likely to be 'discredited' (Goffman, 1963/1990) in that context. Welfare stigma was related to receiving employment benefits, of which the majority of the participants in our sample were recipients. The participants talked about the experiences of welfare stigma primarily in the context of their visits to Jobcentres Plus.

Unemployed stigma. Involuntary unemployment led the participants to become members of a social category, that of the 'unemployed', which they often lived as a 'spoiled identity'

This is the accepted manuscript version for the article published in Health (London):

Giuntoli, G., Hughes, S., Karban, K., \& South, J. (2014). Towards a middle-range theory of mental health and well-being effects of employment transitions: Findings from a qualitative study on unemployment during the 2009-2010 economic recession. Health (London) Published online before print October 15, 2014, doi: 10.1177/1363459314554314 
(Goffman, 1963/1990). Such a social identity was spoiled, that is disqualified by others from full social acceptance, and therefore stigmatised on the grounds that being unemployed was a 'blemish' (Goffman, 1963/1990) that consisted both of a certain level of personal failing and of having a diminished moral value.

R1: [When you are unemployed] You become a second class citizen.

R2: When you are unemployed sometimes you tend to live in a different world, you know ... either you are subjected to humiliation right from your family members, right from your wife, your child, your brothers ... [...] Once you are not receiving monthly salary, they look at you as, you know, whatever, they will put you to the rubbish... (Men, 50-65)

R1: They were angry at me 'cause....well, my step dad 'cause he was saying, you should be doing more to find a job and I was getting angry "cause I was applying for jobs and not hearing anything back, so there was a lot of arguing then.

R2: No mine were all right. It's my partner's that were. His mum were nagging him all the time [...] Which did annoy me as well 'cause she were nagging at him. It's like, well, he's looking. What else can he do. It does get annoying.

R3: My family are all right 'cause my mum and dad, they don't work themselves, so they can't say nothing [All laugh] (Women, 18-25)

Although most participants reported experiences of 'moral stigma' because of being unemployed, others thought that there were also other blemishes that could be the cause of their stigma, for example the part of town from which they came. This latter stigma was an example of 'tribal stigma' (Goffman, 1963/1990), that is a trait that is transmitted through lineages and disqualifies an entire group, for example one's ethnic group, nationality or, in this case, place of origin. However, often the participants resisted their stigmatisation and

This is the accepted manuscript version for the article published in Health (London):

Giuntoli, G., Hughes, S., Karban, K., \& South, J. (2014). Towards a middle-range theory of mental health and well-being effects of employment transitions: Findings from a qualitative study on unemployment during the 2009-2010 economic recession. Health (London) Published online before print October 15, 2014, doi: 10.1177/1363459314554314 
distanced themselves from the blemishes they were associated with in order to salvage their personal identity. For example, the third participant in the extract below engages in a deflecting, 'that's not me' strategy (Thoits, 2011), through which she suggests that the proposed stereotype or blemish is inapplicable to her.

R1: I think it's just today's society. If you don't have a job, then you're just lower than everybody.

R2: I think it's the areas you come from as well. It's what you see.

R3: No, I don't really say that because, like, I come off of an estate but I don't do the things that people might do on my estate... (Women, 18-25)

Although the experiences of unemployed stigma were examples of social stigma related to personal or moral blemishes, one woman reported her concern that her unemployment stigma could pass on to her children. This concern suggests the possibility that the participants' moral stigma could transform into a tribal stigma. This fear shows the power of stigma and the profound effects that it can have not only on people's identities and wellbeing, but also in replicating, maintaining, and reinforcing social inequalities.

I don't want them [her children] stigmatised like everybody else, oh you're not working, your mum just sits on, you know she's another dole dosser (Women, 26-49).

Overall, the findings showed that the participants experienced different forms of self-stigma, which is the "internalization of the stigma responses from the general public by the target individuals" (Mak et al., 2007), rather than experiences of direct discrimination. Only one participant reported an experience of direct discrimation in the form of explicit verbal abuse (enacted stigma) from passers-by. However, this was not simply the outcome of him being unemployed but also of living in a hostel for homeless people, where he ended up as a

This is the accepted manuscript version for the article published in Health (London): 
consequence of lack of family support and not having received his redundancy pay because the firm for which he worked for many years went into liquidation.

Welfare stigma. The experience of unemployment led the vast majority of the study participants to embrace the social role of 'jobseekers' (Directgov, 2011), which entailed claiming unemployment benefits through Jobcentre Plus. Such an experience, which is here conceptualised as an intermediate form of 'integrative passage' (see above), did not lead them to gain a higher social status, it rather led them to be associated with a social category that they experienced, once again, as entailing a stigmatised, discreditable social identity: that of the 'dole dosser'. This consisted of the public view of people on unemployment benefits as lazy and unwilling to look for a job, which is here referred to as 'welfare stigma'.

I: What's your initial experience of going to the Jobcentre [Plus] the very first time that you had to go and sign on?

R1: It's embarrassing

R2: It is

R1: You feel like a proper dosser, putting it bluntly, that's what you feel like.

R2: You feel like a liar.

R1: That's how they make you feel as well... (Women, group of 4, 18-25)

R1: ...Everyone just thinks people on the dole, they don't think about the people who have got qualifications and stuff. Everyone just sees people on the dole as dole dossers.

R2: Yeah. 
R1: That's it. It doesn't matter whether you're a nurse, you know, you're qualified to do something or whatever. It doesn't matter. You're just the same.

R3: You're classed as a dole dosser.

R1: You're just a dole dosser (Women, group of 7, 18-25)

In this case too, often participants resisted their welfare stigmatisation using different strategies, from undermining the legitimacy of the stigma through stigmatising the Jobcentre Plus officers as incompetent and inefficient (many frustrating experiences were reported in the focus groups), to distancing themselves from others, 'undeserving' unemployed individuals, such as long term unemployed people.

R1: People with children shouldn't be thinking it's alright to sit there and just do nowt, you know. And that's the people that are spoiling it for the people that do need it [...] 'cause then they tar you all with the same brush (Women, 18-25).

However, these were all examples of 'individual mobility' strategies, that is strategies through which people dissociate themselves from their stigmatised group and work on their own to re-join high-status (Haslam et al., 2009). None of the participants reported attempting to improve their group's situation by trying to replace the negative labels with more positive ones ('social creativity' strategies), or getting involved in political action to secure improved rights or better treatment for unemployed people.

\section{Discussion}

This study has used Ezzy's (1993) middle-range theory of job loss as a status passage as a theoretical lens to analyse the experiences of unemployment of people who became jobless during the 2009-2010 economic recession. The study findings showed that the study participants experienced involuntary unemployment as a divestment passage, bringing some 
first empirical evidence that is consistent with Ezzy's (1993) original proposal. However, the findings also showed that, for many participants, the experience of unemployment was also characterised by an intermediate form of integrative passage: becoming a 'jobseeker'. This latter finding helps us to expand on Ezzy's (1993) original proposal by showing that the experience of involuntary unemployment can affect people's mental well-being because of the transitory new roles and statuses that people can take up as a result of being unemployed, not just because of the loss of role and status that comes with unemployment.

Overall, the analyses showed that the divestment passage and the integrative passage were characterised by three main properties: reduced agency, disruption of role-based identities, and experiences of 'spoiled identities'. The participants' discussions of their experiences of unemployment provided data to identify the main thrust of each property on both main components of their mental well-being, that is their emotions and feelings of satisfaction (i.e. hedonic well-being), and how they functioned individually and socially (i.e. eudaimonic wellbeing). In particular, the focus on the eudaimonic elements of the participants' well-being helped to bring to the fore and discuss not only their intra-personal experiences of unemployment, but also their inter-personal ones, which are too often neglected in current research. However, the article has not explored the role played by individual characteristics such as age and gender in the construction of the participants' identities and, consequently, in their experiences of the unemployment status passages. This limit is related to the fact that the Bradford study, on which the analyses drew, explored age and gender differences in relation to the participants' experiences of access to and use of services. Richer and more nuanced data, possibly from individual interviews, is needed to investigate age and gender issues in employment passages and how these can contribute to the further development of the proposed middle-range theory.

This is the accepted manuscript version for the article published in Health (London): 
The property 'disruption of role-based identities' referred to the participants' current and past work role-performances, i.e. their current lack of a work-role, the difficulties that they experienced in finding a new work-role, and the importance that their past work-role had for their self-identity. This property is consistent with Ezzy's (1993) original proposal to refer to identity theory and to consider the centrality of work-roles as a key property of unemployment status passages, so it could be re-named 'work-role centrality' property. The experiences of loss of time structure and of identity crises, which were at the basis of this property, are also consistent with the findings of previous research (e.g. Jahoda, 1982; Warr, 1987).

On the other hand, the property 'reduced agency' referred to the participants' current and future role-performances, that is their capacity to engage with their everyday life activities and longer term plans. It showed the importance of financial hardships in limiting not only unemployed people's access to basic material resources, so their living standards, but also the potential to fulfil social expectations directly and indirectly related to their social roles and status, so their social well-being. Compared to the 'work-role centrality' property (i.e. 'disruption of role based identities'), this property has brought a new temporal focus, more oriented towards the present and the future, in the evaluation of the impact of involuntary unemployment on people's mental well-being. This importance given to the issue of time in people's experiences of unemployment is consistent with previous studies (e.g. Ezzy, 2001; Fryer, 1986) and moves the discussion forward compared to classic time or stage frameworks (see Table 1). Overall, the concept of 'reduced agency' is consistent with Fryer's (1986) agency theory, however, in the middle-range theory here proposed agency is but one of the three main properties of job loss as a status passage through which unemployment affects people's mental well-being, not the main one as in Fryer's theory (see Table 1 and below).

This is the accepted manuscript version for the article published in Health (London): 
Similarly to 'reduced agency', the property 'experiences of spoiled identities' is also characterised by a temporal focus oriented towards the present and the future. It showed the importance of complementing evaluations of the centrality of people's past work-roles with evaluations of the social value that they attach to the new groups which they join and to their new social roles. With regard to this, this study has brought some first empirical evidence that social identity theory can help explore people's inter-personal experiences of unemployment over and beyond the theoretical insights achieved by referring to identity theory, as originally suggested by Ezzy (1993). Overall, the findings related to this property showed that the participants experienced different forms of self-stigma, i.e. unemployed stigma and welfare stigma, which are consistent with the findings from the sociological and social policy literature on the perception of unemployed and poor people as 'shirkers' and undeserving (Phillips, 2006; Garthwaite, 2011). Research has evidenced that self-stigma can have significant negative effects on people's mental health (Mak et al., 2007), especially when different stigmas are experienced together (Link and Phelan, 2006). Although the participants reacted to their stigmatisation, the study has shown that they favoured strategies of 'individual mobility' in their reactions. This may imply that, contrary to what hypothesised in some quantitative studies (e.g. Jackson and Warr, 1987), job loss at times of economic crises may not necessarily entail the construction of networks of supports or the attribution of job loss to external factors. The variety of backgrounds of unemployed people at times of economic recession might not favour the establishment of support networks that would help the construction of a common social identity as 'victims' of the economic situation.

From a policy perspective, and consistently with studies that have not found empirical support for 'incentive theories' of unemployment (see Table 1), this study suggests that if involuntary unemployed people experience any disincentives to re-join the labour market, these are not related to too generous welfare provisions, but rather to the negative effects that unemployment has on their mental well-being. Consequently, it seems important to

This is the accepted manuscript version for the article published in Health (London): 
complement active labour market policy measures informed by 'incentive theories' with welfare interventions aimed at offering adequate financial support and economic interventions which stimulate job creation.

Overall, this study's findings bring some first empirical evidence to underpin a middle-range theory of the health effects of employment transitions. Middle-range theories "are sufficiently abstract to deal with differing spheres of social behavior and social structure, so that they transcend sheer description and empirical generalization" (Merton, 1968: 68). One of the main characteristics of middle range theories is that they consolidate and federate hypotheses and empirical regularities which otherwise would appear segregated (Boudon, 1991). The proposed middle-range theory suggests that the effects on people's mental wellbeing of their experiences of employment transitions, such as for example their pathways out of and into employment, are primarily related to the properties of those passages.

Importantly, such properties are not objectively defined characteristics (e.g. needs), they are rather intimately linked with people's perspectives and experiences of their employment passages. The three properties identified in this study for the employment passage job loss at times of economic recessions bring together three sets of hypotheses and empirical findings within a common framework. Although these factors are also included in Jahoda's (1982), Warr's (1987) and Fryer's (1986) models, these models do not fully account for people's own interpretations of such factors, that is for the personal and social meanings that they give to them. The capacity of the proposed middle-range theory to account for people's meaning-making processes in the explanation of their pathways out of and into employment is novel and brings a new focus on the social processes and causal mechanisms at the interface between the social context and people's perceptions. This new focus allows researchers to overcome the limits of individual-centred theoretical frameworks - such as set-point theory, which undervalues the causal power of the social context - as well as the limits of situation-centred models, which are mostly informed by needs-based frameworks

This is the accepted manuscript version for the article published in Health (London): 
and tend to overlook the interaction between the social context and people's meaning-

making processes (see Table 1). Consequently, the proposed middle-range theory enables researchers to elaborate more complex hypotheses and calls for more qualitative and quantitative studies on the impact that employment transitions can have on the mental wellbeing of different groups of people and in different socio-economic contexts. 


\section{References}

Boudon R. (1991) What middle-range theories are. Contemporary Sociology 20(4): 519-522.

Boyce M, Secker J, Johnson R, et al. (2008) Mental health service users' experiences of returning to paid employment. Disability \& Society 23: 77-88.

Braun V and Clarke V. (2006) Using thematic analysis in psychology. Qualitative Research in Psychology 3: 77-101.

Directgov. (2011) Jobseekers. Available at:

http://www.direct.gov.uk/en/Employment/Jobseekers/index.htm.

Dooley D and Prause J. (2004) The social costs of underemployment. Inadequate employment as disguised unemployment, Cambridge: Cambridge University Press.

Ervasti $\mathrm{H}$ and Venetoklis T. (2010) Unemployment and subjective well-being. Acta Sociologica 53: 119-139.

Ezzy D. (1993) Unemployment and mental health: A critical review. Social Science \& Medicine 37: 41-52.

Ezzy D. (2001) Narrating unemployment, Burlington: Ashgate.

Finch J. (1987) The vignette technique in survey research. Sociology 21: 105-114.

Fryer D. (1986) Employment deprivation and personal agency during unemployment: A critical discussion of Jahoda's explanation of the psychological effects of unemployment. Social Behaviour 1: 3-23.

Gabriel Y, Gray DE and Goregaokar H. (2010) Temporary derailment or the end of the line? Managers coping with unemployment at 50. Organization Studies 31: 1687-1712.

Garthwaite, K. (2011) The language of shirkers and scroungers? Talking about illness, disability and coalition welfare reform, Disability \& Society, 26, 3, 369-372.

Goffman E. (1963/1990) Stigma: Notes on the management of spoiled identity, Harmondsworth: Penguin.

Gunnell D, Platt S and Hawton K. (2009) The economic crisis and suicide. BMJ 338: b1891.

This is the accepted manuscript version for the article published in Health (London):

Giuntoli, G., Hughes, S., Karban, K., \& South, J. (2014). Towards a middle-range theory of mental health and well-being effects of employment transitions: Findings from a qualitative study on unemployment during the 2009-2010 economic recession. Health (London) Published online before print October 15, 2014, doi: 10.1177/1363459314554314 
Haslam AS, Jetten J, Postmes T, et al. (2009) Social identity, health and well-being: An emerging agenda for applied psychology. Applied Psychology 58: 1-23.

Jackson PR and Warr P. (1987) Mental health of unemployed men in different parts of England and Wales. British Medical Journal 295: 525.

Jahoda M. (1982) Employment and unemployment: A social psychological analysis, New York: Cambridge University Press.

Keyes C and Annas J. (2009) Feeling good and functioning well: Distinctive concepts in ancient philosophy and contemporary science. The Journal of Positive Psychology 4: 197-201.

Link BG and Phelan JC. (2006) Stigma and its public health implications. The Lancet 367: 528529.

Lucas RE, Clark AE, Georgellis Y, et al. (2004) Unemployment alters the set point for life satisfaction. Psychological Science 15: 8-13.

Mak WWS, Poon CYM, Pun LYK, et al. (2007) Meta-analysis of stigma and mental health. Social Science \& Medicine 65: 245-261.

McKee-Ryan F, Song Z, Wanberg CR, et al. (2005) Psychological and physical well-being during unemployment: A meta-analytic study. Journal of Applied Psychology 90: 53-76.

Merton RK. (1968) Social theory and social structure, New York: Free Press.

Miles MB and Huberman AM. (1994) Qualitative data analysis: An expanded sourcebook, Thousand Oaks: Sage Publications.

Mind. (2013) Mental health: Facts and Statistics. Available at: http://www.mind.org.uk/mental_health_a-z/8105_mental_health_facts_and_statistics.

Paul KI and Moser K. (2006) Incongruence as an explanation for the negative mental health effects of unemployment: Meta-analytic evidence. Journal of Occupational \& Organizational Psychology 79: 595-621.

Paul KI and Moser K. (2009) Unemployment impairs mental health: Meta-analyses. Journal of Vocational Behavior 74: 264-282.

Phillips, D. (2006) Poverty and wealth, inclusion and exclusion: Social processes and social outcomes, In Phillips, D. (ed) Quality of life. Concept, policy and practice, London: Routledge. pp. 104-131.

This is the accepted manuscript version for the article published in Health (London):

Giuntoli, G., Hughes, S., Karban, K., \& South, J. (2014). Towards a middle-range theory of mental health and well-being effects of employment transitions: Findings from a qualitative study on unemployment during the 2009-2010 economic recession. Health (London) Published online before print October 15, 2014, doi: 10.1177/1363459314554314 
Stets JE and Burke PJ. (2000) Identity theory and social identity theory. Social Psychology Quarterly 63: 224-237.

Strycker S. (1980) Symbolic interactionism. A social structure version, California: Benjamin Cummings.

Thoits PA. (2011) Resisting the stigma of mental illness. Social Psychology Quarterly 74: 6-28.

Wanberg CR. (2012) The individual experience of unemployment. Annual Review of Psychology 63: 369-396.

Warr P. (1987) Work, unemployment and mental health, Oxford: Oxford University Press.

Welch S, Brugha T, King M, et al. (2011) Mental well-being and mental illness: Findings from the Adult Psychiatric Morbidity Survey for England 2007. The British Journal of Psychiatry 199: 23-28. 